\title{
Az ionok szerepe a membrános múveleteknél
}

\author{
BÉLAFINÉ BAKÓ Katalin*, NEMESTÓTHY Nándor és GUBICZA László \\ Pannon Egyetem, Biomérnöki, Membrántechológiai és Energetikai Kutató Intézet, 8200 Veszprém, Egyetem u. 10.
}

\section{Bevezetés, alapfogalmak}

Az ionok és a membránok közös története 1953-ig nyúlik vissza, amikor W. Juda és W.A. MacRea, az Ionics Incorporation munkatársa szabadalmat1 nyújtottak be „Ion exchange materials and method of making and using the same" cimmel (US 2, 636, 8519), amelyben szulfonsav csoportokat tartalmazó, ionos karakterü polimer membrán készítési módját írták le.

A membránok anyagába juttatott vagy felületére rögzített ionok és ellenionjaik - az ioncserélő gyantákhoz hasonlóan ioncserére (is) képesek, ezért ezeket ioncserélő membránoknak hívták. Itt is megkülönböztethetünk anion és kation cserélő membránokat.

$\mathrm{Az}$ ionos (ioncserélő) membránok ${ }^{2}$ szerkezetileg lehetnek heterogének és homogének, ezek előállítása alapvetően különbözik3. A heterogén membránokat ioncserélő gyanta és filmképző polimer összekeverésével készítik, a keverékből filmet öntve. Homogén membránok esetén a már kész polimer filmhez illesztik az ionos csoportot kémiai kötéssel $^{4}$. Ha a membránt pozitív töltésü csoportok ( $\mathrm{pl}$, kvaterner ammónium sók) felvitelével alakítják ki (1. ábra), anion cserélő membránok nyerhetők. Kation cserélő membránok esetén pedig negatív töltésü csoportokat kell alkalmazni, pl. szulfonsav vagy kaboxil csoportokat.
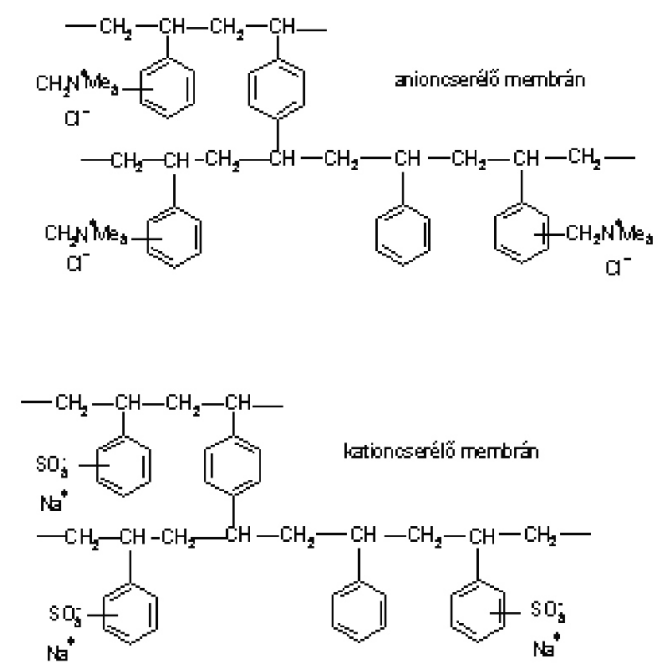

1. Ábra. Anion- és kationcserélő membránok felépítése

\section{Szeparációs müveletek ionos membránokkal}

Az ionos membránok felhasználásával többféle szeparációs müvelet valósítható meg$^{5}$. Az egyik legegyszerübb és legrégebbi ilyen múvelet a membrános elektrolízis, ahol az

* e-mail:bako@almos.uni-pannon.hu eredetileg diafragmával működtetett elektrolízisnél anion illetve kation cserélő membránt alkalmaztak, s így hatékonyabb lett a szeparáció. Ionos membránok beépítésével sókból így savak és lúgok állíthatók elő két cellás elrendezésben, elektromos erőtér (két elektród) alkalmazásával. A müvelet továbbfejlesztett és széles körüen alkalmazott változata az elektrodialízis ${ }^{6}$, ahol kation és anion cserélő membránok egymást követő beillesztésével alakítanak ki cellákat. Az elektromos erőtér hatására a katód illetve az anód felé áramló ionok a membránok segítségével szeparálhatók.

Az elektrodialízis (és a membrános elektrolízis) során ezen ionos membránok funkciója valójában nem ioncsere, hanem az ionok szelektív áteresztése (vagy visszatartása), kialakításuktól függően. Ha ezt elnevezésükben is jelezni akarjuk, talán jogosan hívhatjuk őket ionszelektív membránoknak.

Az elektrodialízis különféle alkalmazásai során ${ }^{7}$ többféle nehézséggel kellett szembenézni. Ide $\operatorname{tartoznak}^{8} \mathrm{pl}$. az ozmotikus áram fellépése, koncentráció polarizáció kialakulása, áramsűrüségi limit megjelenése, szivárgás, eltömődés...stb. Egyes problémák megoldásában segítséget nyújthatnak az ún. bipoláris membránok ${ }^{5}$, amelyek tulajdonképpen egy anion és egy kation szelektív membrán összeragasztásával kialakított kompozit membránok. Funkciójuk a vízbontás, illetve savak, vagy lúgok kinyerése céljából $\mathrm{H}^{+}$vagy $\mathrm{OH}^{-}$ionok biztosítása.

Az ionszelektív membránok nemcsak elektromos erőtérben használhatók ${ }^{2}$. Az ún Donnan dialízis esetén (vagy diffúziós dialízis) lehetséges egyes ionos elválasztása úgy is, hogy nincs elektromos erőtér, csak az egyik fajta (vagy anion, vagy kation szelektív) membránt beépítve az adott ion átjuthat a membránon diffúzió útján, míg az elleniont visszatartja a membrán. Ezt a szeparációs eljárást célszerü akkor alkalmazni, ha az egyik ion jóval nagyobb méretü, s membránon való áthaladása sokkal lassabb lenne.

$\mathrm{Az}$ ún. PEM üzemanyag cellákban szintén ionos membránokat alkalmaznak: ún. protonszelektív (kation szelektív) membránokat ${ }^{9}$, amelyeknek hármas funkciója van:

- Elválasztja az anódot és a katódot

- Megakadályozza az üzemanyag és az oxidálószer összekeveredését

- Átengedi a protonokat

Napjaink egyik legérdekesebb újdonságát jelentik az ionos membránok világában azok a filmek, ahol egy nem-vezető pórusos membránt (pl. ultraszürő membrán) ionos folyadékkal itatnak át, és így biztosítják egyrészt a 
vezetőképességét, másrészt az ionszelektivitását ${ }^{10}$. Ezeket az ún. támasztóréteges folyadékmembránokat nemcsak ionok elválasztására, vagy üzemanyagcellákban lehet felhasználni, hanem pl. olyan gázok szeparációjára is alkalmasak, amelyek polaritásukban eltérő komponenseket tartalmaznak. A szén-dioxid metántól történő elválasztására például sikerrel alkalmazhatók az ún. alkil.alkoxi típusú ionos folyadékok ${ }^{11}$ (2. ábra).

\section{SZERKEZET}

1-(2-etoxi-etil)-3metil-imidazoliumhexafluorofoszfát

$1-\{2-[2-($ etoxi)etoxi]-etil\}-3-metilimidazoliumhexafluorofoszfát $1-[2-\{2-[2-(2-$ etoxi)-etoxi]etoxi\}-etil]-3-metilimidazoliumhexafluorofoszfát 1-(2-metoxi-etil)-3metil-imidazoliumhexafluorofoszfát

\section{KATION}<smiles>CCOCCN1C=[N+](C)CC1</smiles><smiles>CCOCCOCCN1C=[N+](C)CC1</smiles><smiles>CCOCCOCCOCCN1CC[N+]2(C)CC1C2</smiles><smiles>COCCN1CC[NH+](C)C1</smiles>

Az anion minden esetben $\mathrm{PF}_{6}^{-}$volt.

\section{2. Ábra. Alkil-alkoxi típusú ionos folyadékok}

\section{Alkalmazási technikák}

\section{Elektrodialízis szerves savak kinyerésére}

Laboratóriumunkban a fumársav - almasav biokonverzióhoz kapcsolódóan vizsgáltuk az almasav kinyerését ED alkalmazásával ${ }^{12}$. Ehhez egy aszimmetrikus, két kation- és egy anionszelektív membránt tartalmazó ED készüléket állítottunk össze. A feladat az volt, hogy az ammónium maláttól (el nem reagált szubsztrát) elválasszuk az almasavat (termék). A speciális elrendezésnek köszönhetően nemcsak a termék kinyerést lehetett így megoldani, de visszanyertük az ammónium ionokat és a fumársavat is, amelyeket vissza lehetett vezetni a bioreaktorba a további reakcióhoz.

Elektrodialízist használtunk a pektin hidrolízisénél keletkező monomer, a galakturonsav kinyerésére is ${ }^{13}$, amelyet többek között savanyítószerként használnak fel az élelmiszeriparban. A különféle forrásból (pl. gyümölcslé gyártásnál keletkező törkölyök, préslepények és hasonló értéktelen melléktermékek) nyert pektinek hidrolizátumaiból a galakturonsav egy lépésben kinyerhető volt bipoláris ED alkalmazásával.

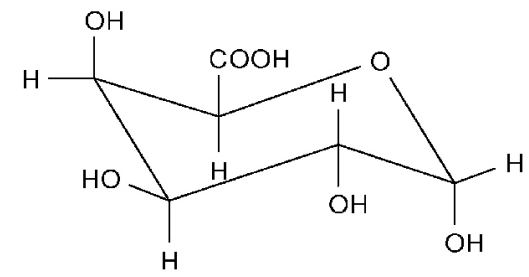

3. Ábra. A galakturonsav szerkezeti képlete

\section{Mikrobiális üzemanyagcellák}

A mikrobiális üzemanyagcellák ${ }^{14}$ olyan bioelektrokémiai rendszerek, ahol kémiai energiából elektromos energia nyerhető mikroorganizmusok katalitikus reakciója során. Az anód és katód cellát általában egy protonszelektív membrán választja el egymástól - hasonlóan a „klasszikus” PEM üzemanyagcellákhoz. Projektünkben például egy cukorrépa üzemben keletkező szennyvizet használtunk fel ${ }^{15}$ elektromos energia generálására hosszabb távú tartamkísérleteinkben $(800$ - 1000 óra), ahol kiinduló mikroba-konzorciumként egy biogáz telepröl származó iszapot alkalmaztunk ${ }^{16}$, s 30-40 Wh/m² energiát tudtunk kinyerni.

Membrános gázszeparáció támasztóréteges ionos folyadék $\underline{\text { membránokkal }}$

Intézetünkben - Magyarországon egyedüliként - több mint 10 éve foglalkozunk membrános gázszeparációval ${ }^{17}$, amit hidrogén, metán, szén-dioxid, nitrogén...stb. tartalmú, különféle összetételü gázok elválasztására használtunk. E szeparációs müveletek megvalósíthatók szervetlen vagy polimer anyagú membránokkal, valamint ún. folyadékmembránokkal, ahol a fluid közeg lehet pl. ionos folyadék is ${ }^{10}$.

A támasztóréteges ionos folyadék membránokkal végzett gázszeparációs méréseink első fázisában az egyes (tiszta) gázokra vonatkozó permeabilitási adatokat határoztuk meg, majd két, illetve többkomponensü modellelegyekkel mértük ki az adott rendszerben a membrán szelektivitását. Végül ipari gázelegyek, gázminták szeparációjának hatékonyságát jellemeztük különféle paraméter beállítások mellett ${ }^{18}$.

\section{Összefoglalás}

$\mathrm{Az}$ ionok, ionos vegyületek elválasztásához egyre gyakrabban alkalmaznak membrános müveleteket, pl. membrános elektrolízist, vagy elektrodialízist. Ezekhez ionszelektív membránokat célszerü felhasználni. Ebben az összeállításban példákon keresztül mutattuk be az alkalmazási lehetőségeket.

\section{Köszönetnyilvánítás}

Kutatómunkánkat támogatta az OTKA K 119940 (2016 2020) és a GINOP-2.3.2-15-2016-00016 (2016-2020) nyilvántartási számú projekt. 


\section{Hivatkozások}

1. Juda, W.; McRea, W.A. Ion exchange materials and method of making and using the same, U.S. Patent 2, 636, 8519

2. Bélafiné Bakó K. Membrános müveletek, Veszprémi Egyetemi Kiadó, Veszprém, 2002.

3. Davis, T. A.; Grebenyuk, V.; Grebenyuk, O. Electromembrane Processes, Membrane Technology in the Chemical Industry, S. P. Nunes and K.-V. Peinemann (ed.), Wiley-VCH, New York, 2001.

4. Scott, K. Handbook of industrial membranes. Amsterdam: Elsevier Advance Technology, 760-770, 1995.

5. Strathmann, H. Ion-exchange membrane separation processes, Elsevier B.V., 2004.

6. McRae, W. A. Electrodialysis, Desalination technology developments and practice, Porteous, Applied Science, New York, 249-264, 1983.

7. Korngold, E.: Electrodialysis - membranes and mass transport, Synthetic Membrane Processes Fundamentals and Water Applications, Academic Press, New York, 1984.

8. Grossman, G., Sonin, A. A.: Membrane fouling in electrodialysis: a model and experiments, Desalination 12 (1973) 107-125 https://doi.org/10.1016/S0011-9164(00)80178-2

9. Bélafiné Bakó K. Legújabb membrántechnikák és alkalmazásaik, Magyar Kémikusok Lapja 61 (2006) 145-152

10. Cserjési, P.; Nemestóthy, N.; Bélafi-Bakó, K. Gas separation properties of supported liquid membranes prepared with unconventional ionic liquids, J. Membr. Sci. 349 (2010) 6-1

https://doi.org/10.1016/j.memsci.2009.10.044

\section{The role of ions in membrane processes}

In membrane separation techniques ions may play different roles. Several membrane process is able to separate charged cations and anions. Moreover integrating certain ions into the membrane selective separation of some (not necessarily ionic) compounds is possible. For separation of ions cation or anion selective membranes are applied in the diffusional dialysis (Donnan dialysis), electrodialysis, membrane electrolysis, electro deionization ...etc. processes.
11. Bélafiné Bakó K., Vass A., Cserjési P., Nemestóthy N. Eljárás gázok szeparációjára alkil-alkoxi típusú ionos folyadékokból előállított támasztóréteges folyadék membránok segítségével, Szabadalom, P 08 00093, 2008

12. Bélafi-Bakó, K.; Nemestóthy, N.; Gubicza, L. Study on application of membrane techniques in bioconversion of fumaric acid to L-malic acid, Desalination 162 (2004) 301-306 https://doi.org/10.1016/S0011-9164(04)00063-3

13. Molnár, E.; Nemestóthy, N.; Bélafi-Bakó, K. Utilisation of bipolar electrodialysis for recovery of galacturonic acid, Desalination 250 (2010) 1128-1131 https://doi.org/10.1016/j.desal.2009.09.124

14. Bélafiné Bakó K., Vajda B. Mikrobiális üzemanyagcellák, Magyar Kémikusok Lapja 65 (2010) 151-153

15. Bélafi-Bakó, K.; Vajda, B.; Nemestóthy, N. Study on operation of a microbial fuel cell using mesophilic anaerobic sludge, Desalination and Water Treatment, 35 (2011) 222-226 https://doi.org/10.5004/dwt.2011.2415

16. Belafi-Bako, K.; Vajda, B.; Bakonyi, P.; Nemestothy, N. Removal of COD by Two-Chamber Microbial Fuel Cells, Technology and Application of Microbial Fuel Cells, Prof. Chin-Tsan Wang (Ed.), InTech, 2014. http://dx.doi.org/10.5772/57200

17. Bélafi-Bakó, K.; Nemestóthy, N.; Bakonyi, P. Separation of gases using membranes containing ionic liquids, in Ionic liquids in separation technology, De Los Rios, A.P., Fernandez, F.J.H (Ed.), Elsevier, Amsterdam, 2014. https://doi.org/10.1016/B978-0-444-63257-9.00008-0

18. Törő, M.; Vágó, Á.; Bélafi-Bakó, K.; Nemestóthy, N. Application assessment of membrane-based gas separation technology, MOL Tudományos Közlemények, 2011/2, 50-57

Supported liquid membranes can be manufactured by impregnation of porous membranes with liquids (e.g. ionic liquids). The selectivity of these membranes are determined by the ions. These membranes can be applied for example separation of gaseous mixtures. Some of the processes, membrane techniques, application possibilities are presented in the paper by providing relevant examples. 